\title{
CONTEMPORARY BIOECONOMICAL PROBLEMS FACING OF THE COMPANIES IN THE TOURISM INDUSTRY
}

\author{
N. Penev* \\ Department of Economics, Faculty of Economics, Trakia University, Stara Zagora, Bulgaria
}

\begin{abstract}
Bulgarian economy is a part of the ongoing worldwide processes of globalization. Of the other part, the importance of the tourism sector of Bulgarian economy is essential. Changing the theoretical and practical knowledge in every field of science should follow the general direction of development. The same goes for accounting. Accountability is related to the effective management of the enterprise. On the other hand, accounting is a "conservative science" but "revolutionary" changed in recent years. This article aims to show the contemporary bioeconomical problems in tourism.
\end{abstract}

Key words: Accounting, Tourism, Financial Reports, Industry, Trade

\section{INTRODUCTION}

Accountancy of each industry is characterized by its special features. As it is typical for the science, the accounting has changed and reached an evolution in theoretical and methodological aspect. In recent years accounting has improved quite logically in public sector, banking, agriculture, tourism and industry. Evolvement of accountancy in these spheres is as a result of the changes of the socio - economical life of our country.

The aim of the presented study is to describe contemporary bioeconomical problems facing of the companies in the tourism industry.

As far as etymology of the word "Tourism" is concerned it has a French origin "tourisme" and it keeps its root in most worldwide known languages. Tourism means holiday, entertainment in general and a tour in particular. Tourism is an economic activity in its essence focused on creating, offering and selling of goods and services, like: hotels, restaurants, tour operators and other supplementary services.

\footnotetext{
*Correspondence to: Nikolai Penev Ivanov, Associate Professor, PhD, Department of Economics, Faculty of Economics, $T$ rakia University, Stara Zagora, Bulgaria, email:penevbg@abv.bg
}

\section{In recent years Bulgaria has become a destination, characterized by:}

- The country has significant natural and cultural - historical tourist resources. This Bulgarian heritage attracts both local and international tourists.

- Sector of tourism in Bulgaria develops with a serious pace in recent years. Significance of the industry is leading for the national economy.

- Problems of the tourism sector are: economical, infrastructural, image, lack of subsidy, restitution processes, old fashioned management, as well as lack of qualified personnel. Having all these in mind Bulgarian country is on the its way to become the main obstacle in the tourism development. Bulgarian business has great contribution for the growth in the tourism sector.

- Economic crisis maintained the image of our country as a significantly cheap destination, with middle range level of the service.

- The assault at Sarafovo airport (Burgas airport), highlighted one more serious problem facing Bulgarian tourism security of the tourists. Geographical position of Bulgaria and the geo interests in the region are most likely to be a reason for the assault, but all that happened came to 
prove, that Bulgarian institutions and tourism sector have to invest in safety.(1)

Effective management of tourist activity is impossible without accounting and economical information, which is created, processes and systemized thanks to the accounting system. Thanks to the financial report of the company, (based on the accounting information) could be received information for the overall business activity of the tourist companies. Main tasks, facing accounting could be described in this way: 1) providing information, necessary for the provision of short-and long term plans and forecast of the tourist companies, as well as exercising current control on their implementation; 2) providing information for system and timely control over protection of property; 3) providing information for conduction of thorough economical analysis of the business activity with the aim of finding reserves in order to increase its effectiveness; 4) providing information about contract implementation with international tour operators, about quality of service delivered to the tourists, for the timely payment with the customers, suppliers and others.

The final phase of the accounting process is connected with formulation and release of the financial report. It includes balance sheet, the income statement of the company, equity report, cash flow statement, accounting policy and the explanations to the report.

Users of the accounting report information could be - shareholders, investors, creditors, national institutions, customers, personnel, suppliers and others. Given the accuracy in the preparation of reports, there might be negative consequences when mistakes are made, which could be due to unqualified staff members, or to random errors in the calculations and computer programs or deliberately provided false information. The last one could reflect the company by changing the real perception of the state of the company, as well as misleading of control and tax authorities, defrauding customers, contractors and the country. Control authorities could be from national institutions - central and local, as well as sector and other authorities, under which supervision is the particular company. For this reason is conducted internal and external audit. For mistakes, depending on type and size, sanctions of different scale are provided.

Regulations in the tourism accounting are associated with a number of laws and regulations that may be specific and general. The general regulate the whole economic and financial activity of the companies, while the specific ones refer to the particular accounting.(2)

To the common regulations are added laws, concerning the activity of the business as far as civil, commercial, contractual, tax etc. right is concerned. In the group of the specific regulations are Accounting Law, International Accounting Standards, National Standards for financial reports for small and middle range companies, Book-keeping of the company.

In Accounting Law is settled the methodology of developing and functioning of the accounting systems, as well as preparation of accounting reports, which describe in a reliable way the property and the financial situation of the company and changes that have occurred, together with realized financial results.

Companies in tourism industry conduct accounting recording in chronological order, and the accounting is being carried out regarding the following principles, common for the accountancy: 1) working company; 2) current charging; 3) comparison between income and expenditure; 4) advantage of the content over form; 5) accurate and fair performance; 6) materiality; 7) cautiousness; 8) historical value; 10) valuable relation between beginning and end balance; 11) documentary validity; 12) possible retention of accounting policy.

Applicable accounting standards in the Republic of Bulgaria are approved by Council of Ministers Decree and their implementation is obligatory for the companies operating on the territory of the country, including the sector of tourism.

Each company has the possibility to accept a book-keeping plan, and following it to conduct its activity. In the plan are included accounts in the following sections: capital, long term assets, inventories, plans, funds, expenses, revenues, balance accounts. Accounts are arranged in sections and groups, using the decimal system for encoding sections, groups, and accounts. Companies develop their individual book-keeping plan, taking into account the specific structures, activities and the accepted by the company organization of accounting. In last decade is observed some „liberalization" of accounting process of the country, and to the individual companies is 
given significant freedom in the process of organizing the accounting.(3)

Main characteristic of the accounting process is a compilation of a large volume of documentation. Accounting document is a written record of information for conducted business operations. Accounting documents could be classified according to different criteria. According to the place of compilation they could be internal and external. External documents are compiled by other companies and come to the company's accounting from outside. Responsible for the accuracy of the information is the person who prepared the document. The one, taking the documents should check the described business activity. Such documents are an invoice for bought goods and services, payment and banking documents and others.

Internal documents, are those issued by the company - cash, warehousing, production and other documents. According to accounting law reliability for information in accounting documents and in their informational carriers are responsible the authorities who have compiled them and signed them. Persons who have ordered the execution of business operations, are responsible for their legality and appropriateness. It is necessary to differentiate the responsibility of the ones, who have a particular operation done, from responsibility of employees from the accounting, who only transform these orders in accounting documents. Responsibility for accounting in tourism is given to the chief accountant.

Depending on the character of information, which they carry documents might be divided into: primary, secondary and records. Primary document has information about a first recorded business operation. Secondary documents carry summarized information, received by the primary ones. The record keeps chronologically systemized information for business operations from primary and secondary accounting documents. Accounting records are special types of secondary documents, which contain summarized information, already mentioned in both primary and secondary accounting documents. Accounting records are the books for income and expenditures, inventory ledger, book inventories, cash book and others.

Documentation process is the way of movement of the accounting documents from the moment of their compilation or when they are received in the enterprise till the moment when they are submitted in the permanent accounting archive for storage.(4)

$* * *$

Contemporary economic conditions in tourism industry require evolvement of systems of processing and storage of accounting information. Security of information raises problems of a particular type. In the development of automatic processing of accounting information in tourism, is ensured integrity of performance of indexes and requisites, used in accountancy for individual sites, as well as organization of informational relations of each site with the other ones. The reason behind this, is that often in the tourist complex are situated a lot of separate sites, offering different products and services.

In processing accounting information in tourism, it is classified and encoded, by providing full coverage of all the classification objects; with a possibility to include new classification groups and objects; automatically are received all accounting indexes separately or grouped according to different feature; commonly used specifications and encoding systems.

Book-keeping plan of the tourist company is a basis for classification in computer processing of accounting information, and documentary gathering of business operations is carried out following the regulations of the accounting law and law for accounting standards. Information from primary and other accounting documents form informational basis, needed for the functioning of the accounting system in the tourist organization.(5)

Main role in accounting of organizations of tourism industry plays the chief accountant. $\mathrm{He}$ defines the form of the accounting. Form of accounting ensures preliminary current control over the primary accounting information from implementation of tourist activity; synchronized implementation of chronological and systematical /analytical, synthetically/ accountancy; openness of the system of accounting in order to achieve additional management tasks; logical transformation of accounting information in its processing and usage; presenting necessary accounting information for motivated management decisions, for taxation and the protection of property, which in tourism industry is specific. 
Main characteristics of accounting information in tourism do not differentiate compared to other industries. Objectivity, accuracy, completeness, reliability, availability, and timeliness of accounting information are important for its users. Effective management of tourist organization is not possible without accounting, and accounting knowledge of managers is obligatory.

Next highlight $\mathrm{f}$ the study, is related to the contemporary problems facing accountancy of tourism industry and it is the problem of financial and tax control over the activity of the sector. Creating statistical information and realization of business analysis in the sector is in direct relation with the effectiveness of the management.

Management personnel and human factor in tourism industry have unique significance. The reason behind this is the specific business tourism creates emotions, sensations, experience and conditions for relax of the guests - both physical and mental. All these make personnel exclusively important factor in the overall tourist perception of the product. Motivation of staff, wages, relations with them are interrelated.

When describing contemporary theoreticallymethodological problems facing accountancy of organizations in tourism industry is necessary to pay attention to accounting. In preparation of sample book-keeping plan of tourist enterprise are followed the main rules, common for the accounting of other sectors in the industry. Sections of book-keeping plan of tourist enterprise are the following: accounts for capital; accounts for long term assets; accounts for short term assets (inventories, production, goods etc.); accounts on claims and liabilities of the company; financial accounts; accounts of expenditure; accounts for revenue, accounts for contingent assets and liabilities. The use of codes is specific for accounting, and it supports and facilitates the work of the chief accountant. (6)

The issue with calculation the cost of the product in the tourism sector is also important nowadays. Bulgarian companies in the sector in recent years offer more often of a full bundle of services (the so called "All inclusive" „everything included") - accommodation, F\&B, supplementary services, entertainment, animation for children, using all the possibilities of the complex and all amenities (SPA and fitness centres, zones for fun, games, etc.). However a partial „discrimination” of the guests is observed. One and the same product is offered on different price. For example for the Bulgarian tourists the price of the product is significantly higher compared to the one offered to international tourists. Paradoxically, but one tourist product, on one and the same place, is offered on higher prices for Bulgarian tourists compared to the international tourists. This is the main problem of the sector. Due to this reason Bulgarian tourists prefer destinations like - Turkey, Greece, Macedonia and Romania, where the expression „All inclusive” almost really means на „everything included". On the other hand this leads to maintained image of the country as cheap destination, with the option ,to be tried" uncountable variety of experience, without any problems with the authorities, owners of tourist properties and Bulgarian society. „Being in servitude" of the idea, that „customer is always right", leads to the following situation:

- Offering relatively cheap low quality product;

- Amortization of long term assets, which is an inevitable process, but on the basis of decreasing revenue of one tourist, would become a problem in the future;

- overbuilding;

- ecological problems;

- not notifying the trends of international tourism.(7)

Presented problems of the study, describe challenges facing not only accountancy in the tourism industry of Bulgaria but also of the management of the system. The national institutions occupied with the problems of the sector, non-government organizations, associations, and most of all enterprises from the tourism industry should take into consideration the international trends of tourism development.

Change of taste of the „global" consumer of the tourist product on an international scale and the outlined problems, in long term plan will lead to a decrease of the revenue from the Bulgarian tourism. This will reflect on problems related to innovations and investments in the sector and in the next years this will only lead to more problems. They could even become more severe because of the geographical position of Bulgaria and the geopolitical and economical interests of the region. Accountancy is part of the management system of the tourist company. The systematical approach in the business activity 
in tourism, requires accounting to be adaptive with fast pace to the new realities, and the accountants themselves to have complex economical knowledge. Nowadays more than ever, in the management of each company of the tourist industry, is required knowledge, skills, flexibility. Only in this way there will be effective counteraction of the crisis situations and sustainability of the development of tourism sector in Bulgaria will be ensured.

The author is grateful to the National Science Program "Healthy Foods for a Strong BioEconomy and Quality of Life", FP 4.3. A new generation of value-added bio-based chains, funded by the Ministry of Education and Science.(8)

\section{REFRENCES}

1. Nenova, R., Agricultural holdings - a new manifestation of social agriculture, Dimitar A. Tsenov Academy of Economics Svishtov, Narodnostopanski Archives, 2014, pp 55-70.

2. Nenova, R., Monitoring of agricultural greenhouse gases, Dimitar A. Tsenov Academy of Economics - Svishtov, Narodnostopanski Archives, 2015, pp 7090.

3. Georgieva, E. Legal regulations in support of the agricultural producers in Bulgaria. Plovdiv, Scientifics works, vol. LVI, 2012, Academic Publishing House of Agricultural
University Plovdiv, ISSN 1312-6318-4, p.227-232.

4. Georgieva, E. Options for reporting of depreciation of fixed biological assets according to IAS 41 Agriculture. Electronic journal "Economics and computer science", Volume 2, 2016, ISSN 23677791, Varna, Bulgaria, p.15-22.

5. Georgieva, E., Penev, N. Accounting for the depreciation of the vineyards and its impact on the taxation of the enterprise, International scientific-practical conference "Possibilities for business development economic, management and social dimensions", Svishtov, 2018, v. 1, ISBN 978-954-23-1702-9, p.351-358.

6. Georgieva, E. Penev, N. Accounting opportunities for depreciation of a cow herd. Trakia Journal of Sciences, ISSN 1313-7069/ Volume 15, 2017. Series Social Sciences/p. 223-228.

7. Perkov, V., Classification of European countries by the level of business-tobusiness e-commerce development, Dimitar A. Tsenov Academy of Economics Svishtov, Yearbook, 2016, pp 241-277.

8. Nenova, R., Methodological differences in the environmental footprint, Dimitar A. Tsenov Academy of Economics - Svishtov, Almanac scientific research, Vol. 24, 2017, Part II., pp 179-205. 